\title{
EFFICIENCY OF PHYTOREMEDIATION ON THE SEDIMENTS CO-CONTAMINATED BY HEAVY METALS AND ORGANIC COMPOUNDS AND THE ROLE OF MICROBES IN THE REMEDIATION SYSTEM
}

\author{
JIA, J-L. ${ }^{1 *}-$ ZHAI, X-B. ${ }^{1}-$ BAI, L. ${ }^{1}-$ HU, L. ${ }^{1}-$ LIU, Y. ${ }^{2}-$ LIU, J-L. ${ }^{1}-$ ZONG, S. ${ }^{1}-$ PING, H. ${ }^{1}$ \\ ${ }^{1}$ School of Chemical and Environmental Engineering, China University of Mining \& Technology, \\ Beijing, 100083, China \\ ${ }^{2}$ Yanqing Country Water Authority, Beijing, 100083, China \\ (phone: +86 13810103722) \\ *Corresponding author \\ e-mail: jiajianli77@126.com
}

(Received $3^{\text {rd }}$ Aug 2016; accepted $26^{\text {th }}$ Sep 2016)

\begin{abstract}
This paper presents the findings of a one-year research project, in which participants explored the function of microbe remediation efficiency and plant growth. Corn and rye grass were planted separately and in mixed quantities to remediate sediments co-contaminated by heavy metals and typical polycyclic aromatic hydrocarbons (PAHs). The study revealed that both the number and the activity of microbes were affected during the sediment remediation process. It also showed that the overall trend at first increased and then decreased, with the microbial numbers reaching their highest levels during the second week of soil cultivation. In the heavy-metal, organic-compound, co-contaminated matrix, the researchers found that mono-cropping the corn removed more lead, with the removal rate reaching a high of $12.96 \%$. They found further that in the mixed-planting pattern, the removal rate of zinc reached a maximum level of $31.4 \%$. The results of the study showed conclusive evidence that organic matters play an important role in the plant-microbe remediation of contaminated sediments.
\end{abstract}

Keywords: combined contamination, PAHs, corn, rye grass, microorganism

\section{Introduction}

There has been great progress in environmental research in recent years and, in the course of these studies, much attention has been drawn to the damaging effects of pollutants on vegetation (Hou et al., 2014). Researchers have found that great quantities of contaminated sediment exist in organic compounds (Charrasse et al., 2014). The water quality in most cities has deteriorated, and the rivers into which much of the wastewater is deposited has become malodorous, This is due to the high level of alluvial-contaminated sediment which remains in the water long after the pollutants have been introduced (Wang et al., 2015). Too, the re-release of pollutants from the contaminated sediment has become a secondary source of pollution in the affected rivers (Kadhum et al., 2015; Varjo et al., 2003; Prajith et al., 2015). It is imperative that these issues be addressed, governed, and corrected with dispatch.

The very nature of heavy metals is that they remain stable (Tian et al., 2015). Once they have been deposited into the soil, they cannot be decomposed by microorganisms. Heavy metals not only pollute groundwater (Zhao et al., 2006), but they also inhibit plant 
growth and development. Besides this, they promote premature crop aging, resulting in poor agricultural product quality and smaller crop yields (Wang et al., 2013). Moreover, heavy-metal pollutants pass through the food chain and, ultimately, put the health of consumers at risk. Finally, polycyclic-aromatic-hydrocarbon (PAHs) pollutants wreak havoc on both the biosphere and the environment.

Given these well-documented facts, it comes as no surprise that studies on organic pollution removal have become a "hot topic" in research circles. Integrative sediments are not only quite contaminated, they also have a high-quantity (Xin et al., 2014), high-moisture content, and they contain objectionable constituents like heavy metals, pesticides and organic pollutants. In tandem, these elements are inflicting great damage upon the environment and will continue to do so if they are not properly dealt with (Bastami et al., 2015).

The status of soil health determines its ability to be productive. Researchers have found that phytoremediation is a cost-effective, environmentally-friendly approach to remediating soil that has been defiled by a mixture of organic and metal contaminants (Chirakkara et al., 2015; Lombi et al., 2001). Phytoremediation uses plants to degrade, immobilize, and extract contaminants from the soil and from water sources (Sharma et al., 2004; Ghosh et al, 2005). The capability of these plants to uptake contaminants while continuing to survive in the tainted soil, and the bioavailability of the contaminants in the soil are the limiting factors that influence phytoremediation efficiency (Kaewtubtim, 2016). Heavy metals tend to decrease in the presence of organic contaminants and can thus become a limiting factor in the phytoremediation of mixed-contaminated soil.

In past studies, researchers have tested the combination of phytoremediation with micro-organisms in mixed-contaminated soil (Dhal et al., 2013). Vouillamoz and Milke, for example, have shown convincing evidence that rye grass is effective in removing mixed contaminants from soil (Vouillamoz and Mike, 2001). The most common contaminants found in mixed-contaminated soil (Cheng et al., 2008), such as co-contaminated river sediment are pyrene, phenanthrene, lead and zinc (Wang et al., 2014., Akcil et al., 2015; Nguyen et al., 2015). To date, studies on enhanced phytoremediation have not yet addressed the rhizosphere effect on mixed contaminants (Priha et al., 1999). The existing techniques - phytoremediation and microbial remediation (Wang et al., 2008) have been developed through studies using soil that has been contaminated by either metals or organic contaminants; but no such research has been done using co-contaminated soil. The co-contaminated soil is closer to the actual condition. While some studies have explored the key role of microbial remediation in phytoremediation, they have not addressed the relationship between removal rates and microbial remediation.

This study aimed to investigate the relationship between phytoremediation efficiency and the rhizosphere effect. The researchers who took part tested the phyto-microbial remediation effects on combinational contaminated sediments by using corn and rye grass in potted plant experiments. Tests were conducted to measure both the plants' removal rates and their growth rates and to compare their biomass in soil which had been contaminated by a mixture of organic compounds (pyrene and phenanthrene) and heavy metals (lead and zinc). 


\section{Experiment}

\section{Experimental materials and equipment}

The primordial matrix was prepared by mixing dry river sediment screened with a 2 $\mathrm{mm}$ griddle and soil taken from a Beijing suburb at a ratio of $2: 1$. The primordial matrix was regarded as the control group $(\mathrm{CK})$. The testing matrices that were added contained different proportions of lead, zinc, phenanthrene and pyrene. These were used as the contaminated-sediment samples (A and B) of different pollution levels, and the phenanthrene and pyrene were used to represent the exogenous organic pollutants (PAHs). The moisture content and nutrition level of the samples were adjusted in the laboratory. All of these procedures were followed by a natural decaying process which lasted 10 days, and the physical and chemical properties of the experimental soil was tested in the laboratory (Table 1).

Table 1. The basic characteristics of the testing matrix and sample

\begin{tabular}{c|c|c|c|c|c|c|c}
\hline & $\mathrm{pH}$ & $\begin{array}{c}\text { Lead } \\
(\mathrm{mg} / \mathrm{kg})\end{array}$ & $\begin{array}{c}\text { Zinc } \\
(\mathrm{mg} / \mathrm{kg})\end{array}$ & $\begin{array}{c}\text { Total } \\
\text { organic matter } \\
(\mathrm{mg} / \mathrm{kg})\end{array}$ & $\begin{array}{c}\text { EP } \\
(\mathrm{mg} / \mathrm{kg})\end{array}$ & $\begin{array}{c}\text { EN } \\
(\mathrm{mg} / \mathrm{kg})\end{array}$ & $\begin{array}{c}\text { Moisture content } \\
(\%)\end{array}$ \\
\hline $\mathrm{CK}$ & 6.70 & 33.96 & 103.38 & 745.04 & 1.23 & 104.95 & 21.89 \\
$\mathrm{~A}$ & 6.68 & 260.33 & 301.29 & 770.65 & 1.24 & 132.93 & 11.76 \\
$\mathrm{~B}$ & 6.54 & 570.02 & 605.02 & 895.43 & 1.12 & 118.92 & 9.95 \\
\hline
\end{tabular}

EP: effective phosphorus; EN: effective nitrogen

The researchers chose corn and rye grass as the repairing plants (The Institute of Xinnong Agricultural Technology of Beijing) in the experiment to study the effects of phyto-microbial remediation and different planting patterns on sediments subjected to heavy-metal and organic-compound pollution. The experiments were divided into three categories: Corn Only, Rye Grass Only, and Mixed Planting.

The experimental equipment included; ICP-MS ( Inductively Coupled Plasma Mass Spectrometry) (ELAN DRC-e, Perkin Elmer Limited Company); A Soxhlet extractor (SXT-02, Shanghai Hongji Instrument Limited Company); and an analytical balance (OHAUS- AR2140, Ohaus Limited Company).

\section{Analysis methods}

\section{Heavy metal determination}

$0.04 \mathrm{~g}$ of dry soil was screened through a 200-mesh sieve and boiled in a highpressure digestion tank, and then $2 \mathrm{~mL} \mathrm{HNO}_{3}$ and $200 \mu \mathrm{L} \mathrm{H}_{2} \mathrm{O}_{2}$ were added to the mix. A violent reaction followed which generated a large amount of yellow smog. The sample was then sonicated for 30 minutes and placed on a hot plate $\left(130^{\circ} \mathrm{C}\right)$ until it was almost dry. Next, $\mathrm{HNO}_{3}$ and $\mathrm{HF}$ were put into the tank at a ratio of 1:1 and covered with the lid. 
Finally, the tank was placed into an air oven overnight at a temperature of $170^{\circ} \mathrm{C}$. When the digestion was finished, the digestion liquid was diluted to $80 \mathrm{~g}$ and reserved for the ICP-MS assay later.

\section{Total organic compound determination}

The soil sample was passed through a $2 \mathrm{~mm}$ sieve. About $10 \mathrm{~g}$ of the soil sample was mixed with a small amount of anhydrous magnesium sulfate and ground together thoroughly with a mortar and pestle. The sample was then wrapped in a paper filter and placed into an extractor into which about $80 \mathrm{~mL}$ of chloroform was injected. Adjusted the position to make the condenser pipe, extractor, and extraction bottle keep good contact to each other. Next, the extractor was switched on, and the temperature was set at $75^{\circ} \mathrm{C}$ for 12 hours. A weight measurement was then taken to calculate the total organic content of the soil sample.

\section{Biomass determination}

The determination of the EN and EP of soil sample was developed based on the alkali treatment, and the biomass of soil sample was detected using the most probable number (MPN) (Yu et al., 1990; Jia et al., 2004). A beef-extract-peptone medium (10g/L beef extract, $3 \mathrm{~g} / \mathrm{L}$ peptone) was used to quantify the total microbial density, MPN tubes were cultured for $72 \mathrm{~h}$ at $37^{\circ} \mathrm{C}$.

\section{Results and discussion}

\section{The removal effects under the mono-cropping planting pattern}

The remediation effects of corn

The removal efficiencies and degradation rates of lead, zinc, phenanthrene and pyrene were investigated at different pollution levels (Fig. 1).

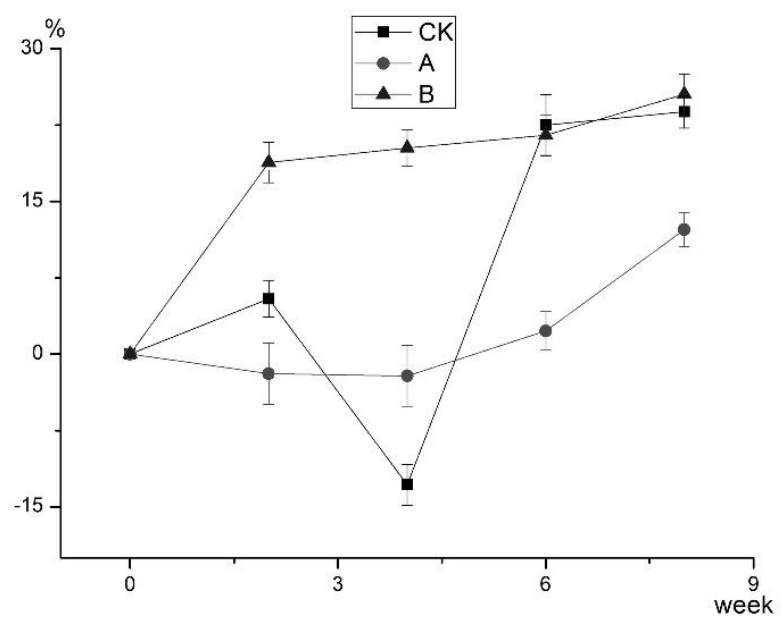



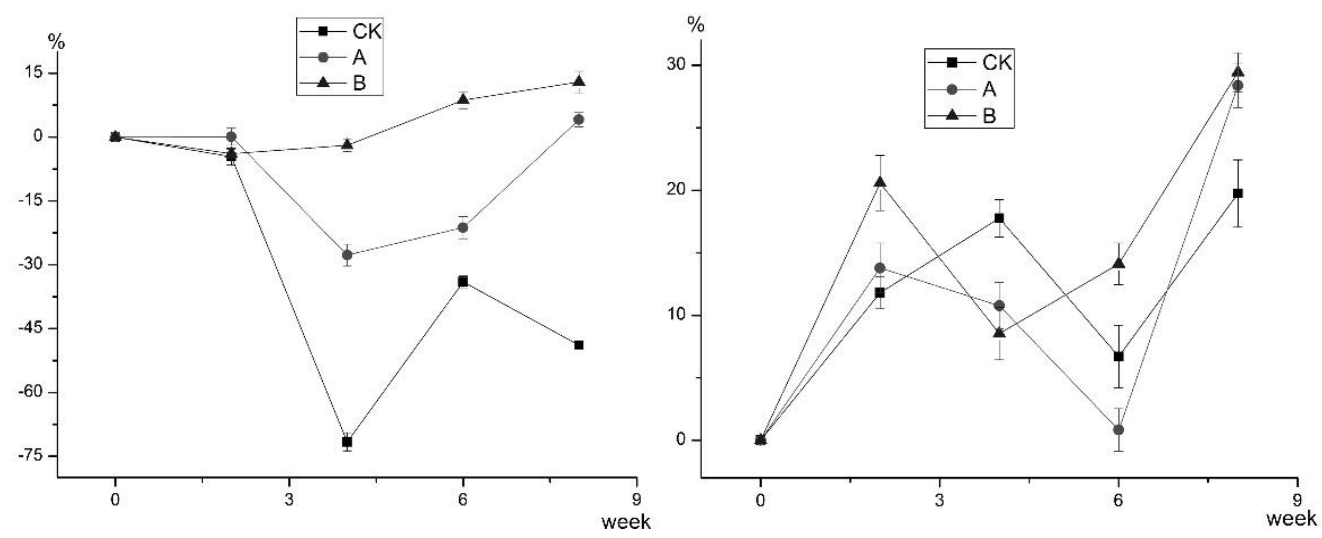

Figure 1. The removal effects of corn on the pollutants. (a) The removal effects on the organic compounds in the sediment; (b) The removal effects on lead in the sediment; (c) The removal effects on zinc in the sediment.

The effects of mono-cropping corn on the combined pollutants of different concentrations are shown in Figure 1. The removal rates of lead in the sediments containing different pollutant concentrations (A and B) were, respectively, $4.08 \%$ and $12.96 \%$. The removal rates of zinc in the sediments were $28.4 \%$ and $29.5 \%$, respectively. Test results showed that the removal of zinc was more effective than that of lead. During the $8^{\text {th }}$ week, the removal rates of organic pollutants were, respectively, $12.24 \%$ and $25.53 \%$ at different concentration levels of pollutants ( $A$ and $\mathrm{B}$ ). The researchers found that with the increase of the pollution level, the removal of organic matters was enhanced. They concluded that this may have been due to the increase of the common stresses of heavy metals and organic matters which are known to promote the absorbance of rhizosphere sediment and the accumulation of organic contaminants by the roots of corn (Ding et al., 2011). The also decided that these organic pollutants could serve as the nutrients which are important for the growth of plants and which the plants may oxidize into $\mathrm{CO}_{2}$ and $\mathrm{H}_{2} \mathrm{O}$. The mycorrhizal fungi and algae in the rhizosphere of corn may not only decompose the organic matter directly, but may also promote the removal of organic pollutants by stimulating the secretion of root exudates of the plants (Zhao et al., 2005).

\section{The remediation effects of rye grass}

The rye grass was grown separately to test its remediation effects. The removal rates and the analytical results are presented in Figure 2. 

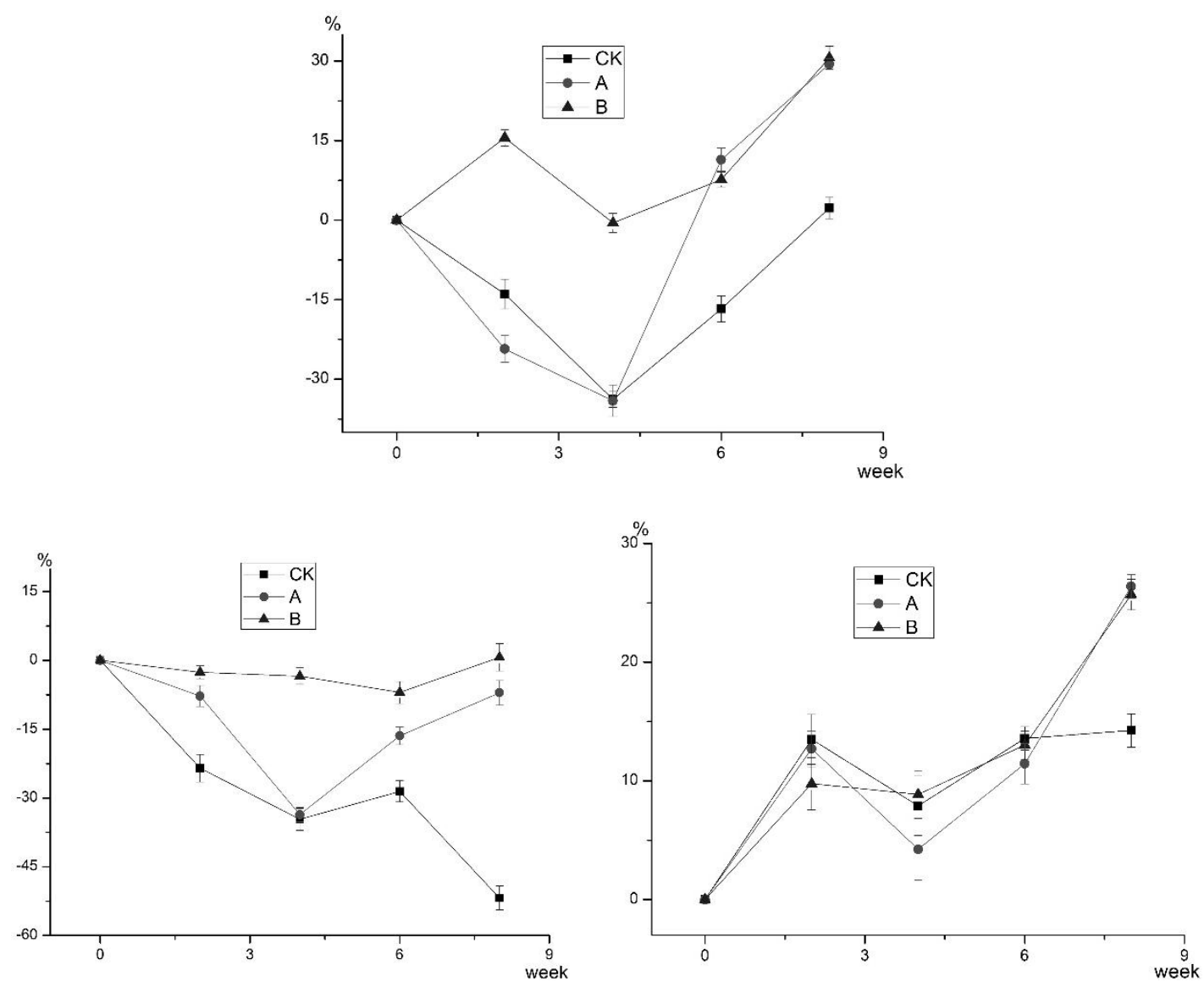

Figure 2. The removal effects of combined pollutants on the treatment of rye grass. (a) The removal effects on the organic matters in the sediment; (b) The removal effects on lead in the sediment; (c) The removal effects on zinc in the sediment.

The experiments conducted on rye grass revealed that the removal rates of lead in the sediment with different levels of pollution (A and B) were $-7.07 \%$ and $0.68 \%$, respectively, while those of zinc were $26.40 \%$ and $25.69 \%$, respectively. Once again, it was found that the removal of zinc was more effective than that of lead. The removal rates of organic matters in the sediments with different concentrations of contaminants reached $29.43 \%$ and $30.62 \%$, respectively. The removal rates of organic pollution from rye grass showed a better efficiency than corn, which was consistent with the research on corn. In addition, the removal rate of zinc was superior to that of lead in the given concentrations. This may have been due to the fact that zinc is an essential element in stimulating plant growth, while lead contains elements of biological toxicity.

In comparison to the tests conducted on corn, rye grass showed lower zinc-removal rates at both concentrations: A. $26.40 \%$ vs. $28.4 \%$ and B. $25.69 \%$ vs. $29.5 \%$. This suggests that the removal efficiency of corn is slightly higher than that of rye grass and may have something to do with the biomass. The mono-cropped rye grass produced a smaller biomass than the corn as was indicated in the biomass tests results. 
The removal efficiency of organic contaminants by rye grass was superior to that of corn. Perhaps this was because perennial rye grass has a higher tolerance of organic matters and to the $\mathrm{pH}$ range of the sediment than corn.

\section{The removal of combined pollutants by a mixed-planting pattern}

The corn and rye grass were planted in a mixed pattern to test the remediation effects on the sediments containing combined pollutants. The removal rates of heavy metal on mixed plants are shown in Figure 3. At concentrations A and B, the removal rates of zinc were $21.2 \%$ and $31.4 \%$, respectively, while those of lead were, respectively, $2.6 \%$ and $4.5 \%$ by the $8^{\text {th }}$ week. These figures fell mid-way between the rates of the two single planting patterns.
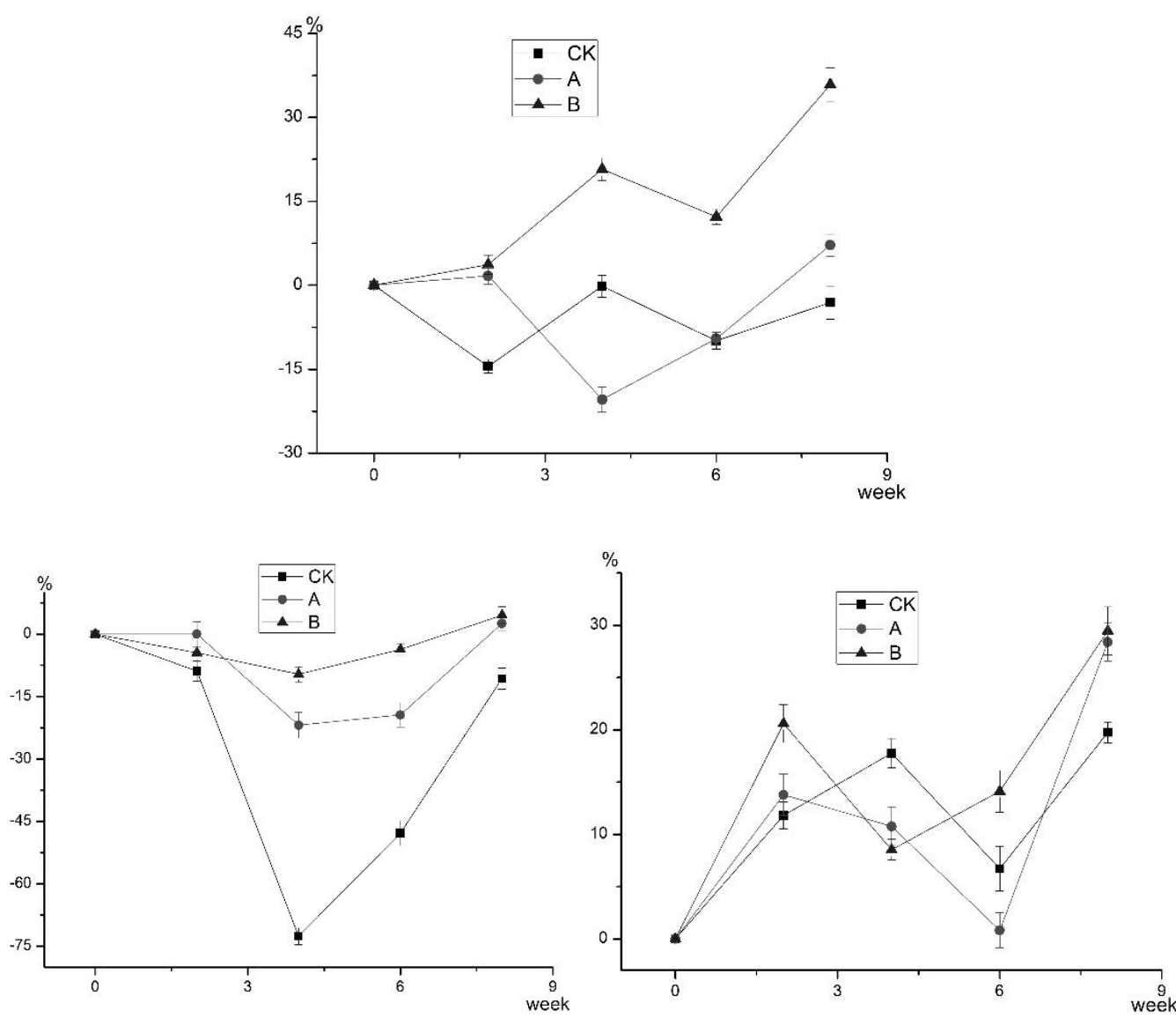

Figure 3. The removal of combined pollutants under mixed plants. (a) The removal effect of organic matters in the sediment; (b) The removal effect of lead in the sediment; (c) The removal effect of zinc in the sediment

At concentrations $\mathrm{A}$ and $\mathrm{B}$, the removal rates of organic pollutants under mixed plants were, respectively, $7.15 \%$ and $35.86 \%$ by the $8^{\text {th }}$ week. The removal rate of the organic pollutant at concentration A was much lower than that at concentration B. This suggests 
that when the level of the organic pollutant concentration was relatively high the mixed planting pattern was the better choice.

The study showed that phytoremediation resulted from the biological changes that prompted the rhizosphere soil enzyme activity as well as an increase of the microbial quantity. The study showed further that the removal of organic matters by plants is largely due to the plant-rhizosphere effect. On the one hand, the rhizosphere effect increases the removal rate of organic matters by bacteria. On the other hand, the plants secrete matrix substrates for microbial co-metabolism, and they stimulate the microbial mineralization of organic pollutants.

\section{The Effects of the Biomass on Remediation and Plant Growth}

The biomass was the more important factor in the decomposition of pollutants, and the biomass of bacteria in the contaminated soil was various at different concentration of pollutants, and the planting pattern had great effect on the biomass.
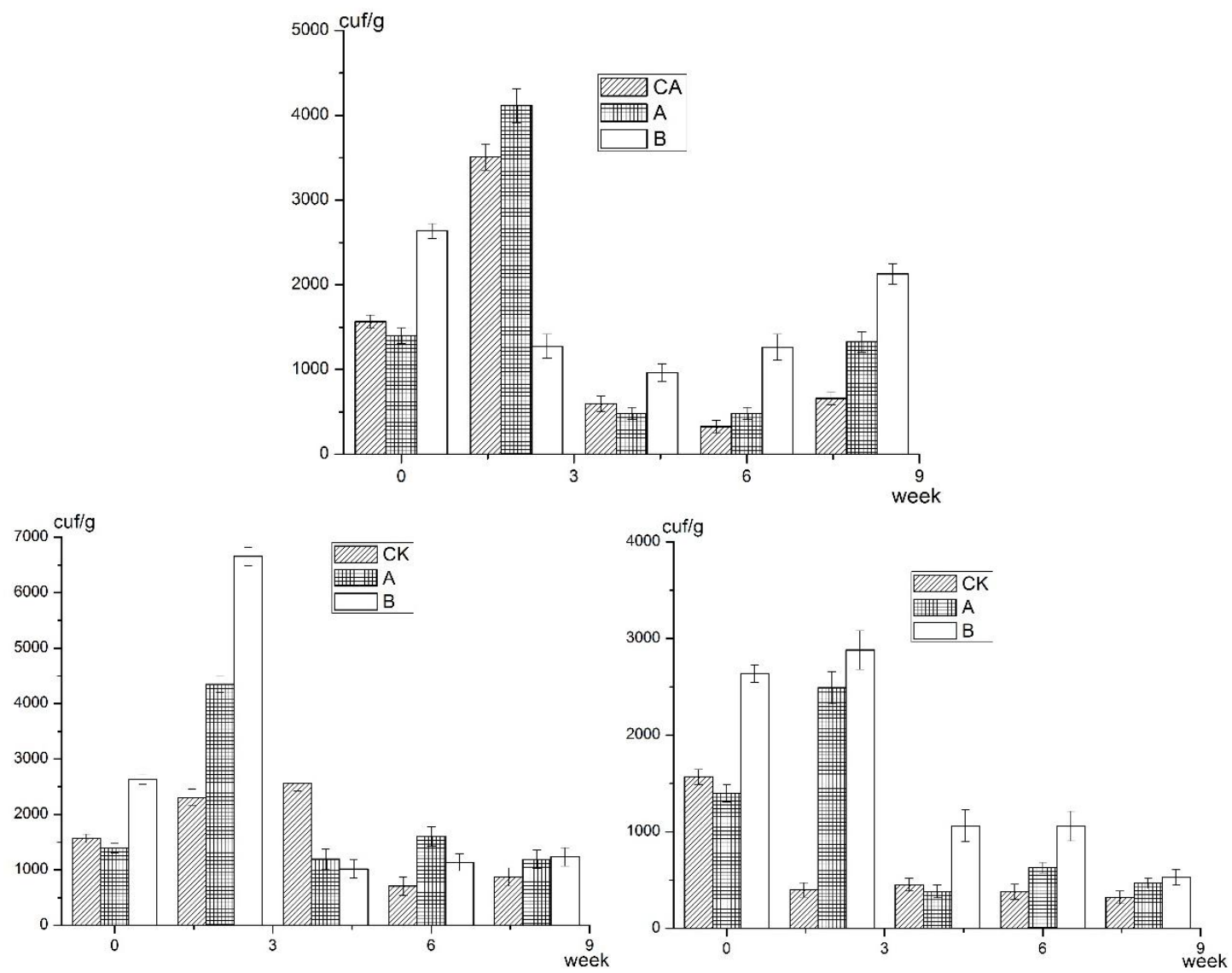

Figure 4. The effects of biomass under different planting patterns. (a)The effect of biomass under mixed planting; (b) The effect of biomass in corn system; $(c)$ The effect of biomass in rye grass system. 
Figure 4 shows that the microbial quantity remained low in the early stages of the test after the pollutants were added to the matrix. After two weeks, the bacteria in the sediment increased dramatically. This may be due to pollution stress, which rapidly generates tolerant bacteria and would be consistent with the removal rates of pollutants In regard to the effects of heavy metals, it could stimulate the microbial proliferation at low concentrations. The bacteria in the sediments reached a maximum high during the $2^{\text {nd }}$ week of the study but fell to a dramatic low during the $4^{\text {th }}$ week and maintained this level until the $8^{\text {th }}$ week. This may have been due to the adaptation of the selection, and the fact that only those tolerant bacteria survived. The heavy metals in the sediments stimulated the multiplication of microbes in the early stages of the experiment, but the microbial biomass in the sediments eventually dropped, because the heavy metals' toxic effects proved heartier than their promotion effects. Thus, the heavy metal' toxic effects negatively affect the sediment microbial flora thereby reducing the sediment microbial biomass.

The organic matters in the sediments also affected the biomass, because the organic matters could be used as carbon source for bacteria. Comparing with CK, addition of exogenous organic matters made the biomass increase at concentration $\mathrm{A}$ and $\mathrm{B}$. The might be that the organic matters could serve as the carbon source, which promotes the microbial growth and reproduction.

\section{Conclusions}

In conclusion, the project participants found that both the biomass and bioactivity were affected by the addition of pollutants, as the biomass at first increased and then decreased in the presence of the exogenous pollutants. These results may have been due to the rhizosphere effect and the stimulation of exogenous pollution. They also found that as the duration of the pollution exposure time increased, a small number of tolerant microorganisms survived and accumulated in quantity. Over time, the variation of microorganisms affected the remediation efficiency.

In the co-contaminated soil, different plant species showed that they had different removal capabilities of lead. In the single-planting patterns, the removal efficiency of corn was better than that of rye grass. The removal rate of zinc by corn was slightly higher than that of rye grass. In addition, the removal rate of heavy metals at concentration B was better than that at concentration A. Within limits, a high concentration of pollutant resulted in positive removal efficiency. The mixed-planting patterns showed a wide range of applications in complex heavy-metal-polluted soil.

The removal effects of combined pollutants is associated with the biomass of lead-zinc-phenanthrene-pyrene combined pollution. They also found that the biomass of tolerant bacteria is critical for the remediation of combined pollution and that organic pollutants could be a crucial carbon source to promote the growth and reproduction of microorganisms. 


$$
-150-
$$

Acknowledgements. This study was supported by the National Natural Science Fund of China (NO.41601336) and the Beijing Natural Science Fund (Development of heavy metal immobilization agents and its control mechanism in the process of urban sewage sludge amended sandy soil, No.8152025).

\section{REFERENCES}

[1] Akcil, A., Erust, C., Ozdemiroglu, S., Fonti, V., Beolchini, F. (2015): A review of approaches and techniques used in aquatic contaminated sediments: metal removal and stabilization by chemical and biotechnological processes. - Journal of Cleaner Production 86: 24-36.

[2] Bastami, K. D., Neyestani, M. R., Shemirani, F., Soltani, F., Haghparast, S., Akbari, A. (2015): Heavy metal pollution assessment in relation to sediment properties in the coastal sediments of the southern caspian sea. - Marine Pollution Bulletin 92(1-2): 237-243.

[3] Charrasse, B., Tixier, C., Hennebert, P., Doumenq, P. (2014): Polyethylene passive samplers to determine sediment-pore water distribution coefficients of persistent organic pollutants in five heavily contaminated dredged sediments. - Science of the Total Environment 472: 1172-1178.

[4] Cheng, K. Y., Lai, K. M., Wong, J. W. C. (2008): Effects of pig manure compost and nonionic-surfactant tween 80 on phenanthrene and pyrene removal from soil vegetated with agropyron elongatum. - Chemosphere 73(5): 791-7.

[5] Chirakkara, R. A., Reddy, K. R. (2015): Biomass and chemical amendments for enhanced phytoremediation of mixed contaminated soils. - Ecological Engineering 85: 265-274.

[6] Dhal, B., Thatoi, H. N., Das, N. N., Pey, B. D. (2013): Cheminform abstract: chemical and microbial remediation of hexavalent chromium from contaminated soil and mining/metallurgical solid waste: a review. - Journal of Hazardous Materials 250-251 C (2): 272-291.

[7] Ding J., Chen. B., Yuan J. J. (2011). Phytoremediation of heavy metals and its endophytic bacteria effects. - Microbiology China 38(6): 921-927.

[8] Ghosh, M., Singh, S. P. (2005): A review on phytoremediation of heavy metals and utilization of its byproducts. - Applied Ecology \& Environmental Research 3(1): 1-18.

[9] Hou, D., Al-Tabbaa, A., Chen, H., Mamic, I. (2014): Factor analysis and structural equation modelling of sustainable behaviour in contaminated land remediation. - Journal of Cleaner Production 84: 439-449.

[10] Jia, J. J., Li G. H., Yi, Z. (2004): The relationship between abiotic factors and microbial activities of microbial eco-system in contaminated soil with petroleum hydrocarbons. Environmental Science 25(3): 110-114.

[11] Jiang, X., Teng, A., Xu, W., Liu, X. (2014): Distribution and pollution assessment of heavy metals in surface sediments in the yellow sea. - Marine Pollution Bulletin 83(1): 366-75.

[12] Kadhum, S. A., Ishak, M. Y., Zulkifli, S. Z., Hashim, R. B. (2015): Evaluation of the status and distributions of heavy metal pollution in surface sediments of the langat river basin in selangor malaysia. - Marine Pollution Bulletin 101(1): 391-396. 
[13] Kaewtubtim, P. (2016): Heavy metal phytoremediation potential of plant species in a mangrove ecosystem in pattani bay, thailand. - Applied Ecology \& Environmental Research 14(1): 367-382.

[14] Lombi, E., Zhao, F. J., Dunham, S. J., Mcgrath, S. P. (2001): Phytoremediation of heavy metal-contaminated soils. - Journal of Environmental Quality 30(6): 1919-1926.

[15] Nguyen, V. K., Tran, T., Han, H. J., Lee, S. H., Lee, J. U. (2015): Possibility of bacterial leaching of antimony, chromium, copper, manganese, nickel, and zinc from contaminated sediment. - Journal of Geochemical Exploration 156: 153-161.

[16] Prajith, A., Rao, V. P., Kessarkar, P. M. (2015): Magnetic properties of sediments in cores from the mandovi estuary, western india: inferences on provenance and pollution. - Marine Pollution Bulletin 99(1-2): 338-345.

[17] Priha, O., Hallantie, T., Smolander, A. (1999): Comparing microbial biomass, denitrification enzyme activity, and numbers of nitrifiers in the rhizospheres of pinus sylvestris, picea abies and betula pendula seedlings by microscale methods. - Biology \& Fertility of Soils 30(1-2): 14-19.

[18] Sharma, H. D., Reddy, K. R. (2004): Geoenvironmental engineering: site remediation, waste containment, and emerging waste management technologies. - Geoenvironmental Engineering: Site Remediation, Waste Containment and Emerging Waste Management Technologies.

[19] Tian, Z., Zhang, B., He, C., Tang, R., Zhao, H., Li, F. (2015): The physiochemical properties and heavy metal pollution of fly ash from municipal solid waste incineration. Process Safety \& Environmental Protection 98: 333-341.

[20] Varjo, E., Liikanen, A., Salonen, V. P., Martikainen, P. J. (2003): A new gypsum-based technique to reduce methane and phophorus release from sediments of eutrophied lakes: (gypsum treatment to reduce internal loading). - Water Research 37(1): 1-10.

[21] Vouillamoz, J., Milke, M. W. (2001): Effect of compost in phytoremediation of diesel-contaminated soils. - Water Science \& Technology A Journal of the International Association on Water Pollution Research 43(2): 291-5.

[22] Wang, J., Zhang, Z. Z., Su, Y. M., Wei, X. F., He, F., He, W. (2008): The rhizosphere effect in phytoremediation of the petroleum polluted soil. - Journal of Petrochemical Universities 21(2): $36-40$

[23] Wang, S. L., Xu, X. R., Sun, Y. X., Liu, J. L., Li, H. B. (2013): Heavy metal pollution in coastal areas of south china: a review. - Marine Pollution Bulletin 76(1-2): 7-15.

[24] Wang, W., Zhang, X., Huang, J., Yan, C., Zhang, Q., Lu, H., et al. (2014): Interactive effects of cadmium and pyrene on contaminant removal from co-contaminated sediment planted with mangrove kandelia obovata, (s. 1.) yong seedlings. - Marine Pollution Bulletin 84(1-2): 306-313.

[25] Wang, Z. H., Feng, J., Nie, X. P. (2015): Recent environmental changes reflected by metals and biogenic elements in sediments from the guishan island, the pearl river estuary, china. Crossings Bulletin of the International Australian Studies Association 164(1 - 4): 493-505.

[26] Yu, Y. X., G. Q. Wu, X. T. Meng. (1990): Measurement Book of Environmental Engineering Microbe. - China Environmental Science Press, Beijing. 
[27] Zhao, X. H., Wei-Fang, M. A., Sun, J. M., Zhang, L. (2006): Effects of rhizosphere in phytoremediation of heavy metal-organic combined contamination in dredged river sediment by maize. - Journal of Agro-Environment Science 25(1): 100-106.

[28] Zhao. X. H., Ma .W. F., Sun. J. M., Tan. H. (2005): Phytoremediation of Heavy Metal Organic Complex in Dredged Sewage River Sediment - Journal of Tianjin University $38(11)$.

\section{APPENDIX}

Appendix 1. The photographs of planted rye grass
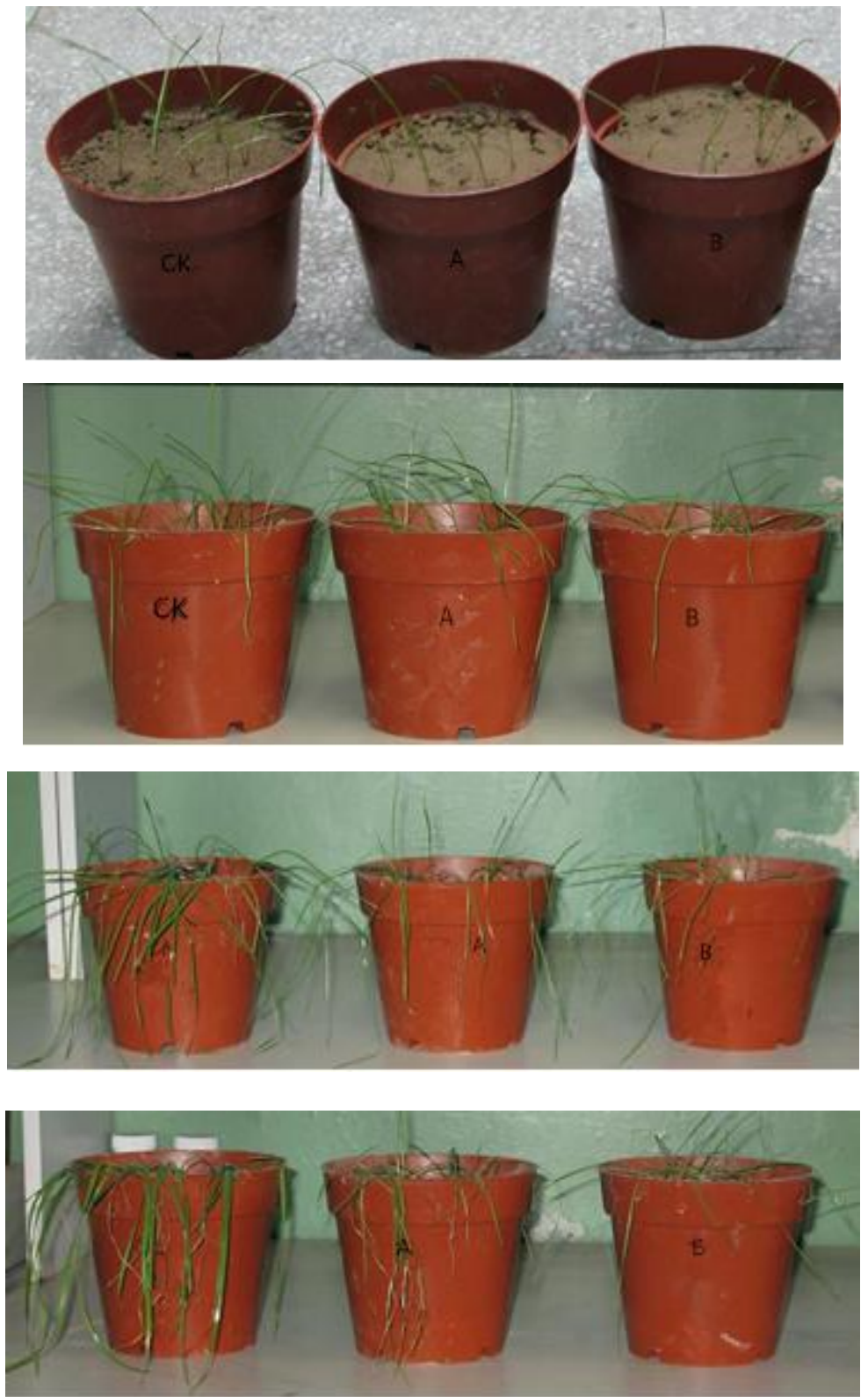